\title{
Research on the Development of Cross-border E-commerce in Jilin Province
}

\author{
Yanni Li, Li Liu, Xiaoyu Liu, Guangxiang Yi, Xiaonan Guan \\ School of Foreign Languages, Changchun Institute of Technology, Changchun, China
}

Keywords: cross-border; E-commerce; One Belt and One Road; Jilin Province.

\begin{abstract}
After 2011, with the continuous development of China's domestic e-commerce, crossborder e-commerce as a unique branch gradually attracts people's attention. This paper focuses on the development of cross-border e-commerce in Jilin Province and tries to find out the advantages of its future trend.
\end{abstract}

\section{Introduction}

The United States is the first country in the world to develop e-commerce and is the most mature country in global e-commerce development. In this field, it has formulated a number of laws including the Uniform Commercial Code, the Uniform Computer Information Exchange Act, and the Electronic Signature Law. As the most powerful international organization in the world economy, the development of the European Union in the field of e-commerce has always been at the leading level in the world. It advocates the independent development of private enterprises, with particular emphasis on the promotion of Internet commercial competition and commercial applications. In Asia, Japan is at the forefront of the development of the e-commerce industry, and has made significant reforms in 2015 in response to the tax system.

At the same time, not only the large-scale import and export business of cross-border e-commerce, but also the amazing development of import and export of small parcels. Such cross-border transactions that directly face consumers are also referred to as "haitao" or "buying". According to the data from the China Electronic Commerce Research Center, in 2013, the transaction volume of overseas cross-border purchasing service exceeded 70 billion yuan, and domestic buyers' direct consumption of Haitao also increased by $117 \%$, far higher than the $64.7 \%$ growth rate of domestic online shopping. . Especially in the context of the "One Belt and One Road" strategy, the development of cross-border e-commerce based on internet technology has become one of the key areas of world concern. Cross-border e-commerce will become a new air "silk road" that cannot be ignored, and will complement and complement each other on the land "One Belt and One Road", especially the impact on Southeast Asian e-commerce market and the cross-border services of Russian e-commerce market will be more prominent.

\section{Research on the Domestic Market}

Some scholars in China have also conducted relevant research as advance soldiers in this field. Peng Long (2015) proposed in the "China's e-Commerce Market Development Report - 2014, What E-Commerce Companies Are Doing" that in 2014, a number of cross-border E-Commerce products had risen to the forefront and were presented in categories such as food and healthy mothers and babies. With explosive growth, the development of cross-border e-commerce is also being constrained by technologies and policies in logistics, credit and payment, and more room for development depends on technological innovation and the gradual opening up of policies. Weng Jinyang (2015) also stated in the "Barbarian Pathfinder" in the era of "re-border cross-border ecommerce - the era of disruptive business" that in 2013, there were more than 5,000 cross-border ecommerce platform companies in China, and the territory passed various types of There are more than 200,000 foreign trade companies that conduct cross-border e-commerce business on the platform, and the national cross-border e-commerce transaction volume has reached 3.1 trillion yuan. On the 
one hand, domestic e-commerce giants have laid out their cross-border e-commerce business; on the other hand, traditional foreign trade enterprises have collectively transformed themselves into crossborder e-commerce. And from the perspective of the market space in the foreign trade field, crossborder e-commerce is ushering in a new "golden age."

In recent years, the growth rate of China's foreign trade exports has continuously declined, while the cross-border e-commerce transactions have maintained a strong growth momentum. Zhou Ning and Zhang Linglu (2014) pointed out the problem of cross-border e-commerce in logistics in the "Foreign trade e-commerce positioning: The way to achieve success for online merchants" and believe that although foreign trade B2C increasingly shows a strong growth momentum, cross-border logistics has been It is a key factor that restricts the development of cross-border e-commerce. How to formulate a set of sound and practical logistics supply chain service solutions to achieve the "threein-one" logistics, information flow, capital flow, so that "Chinese brands" to the world, this is the cross-border e-commerce practitioners can not be avoided problem.

In addition to relevant scholars' research on cross-border e-commerce, Alibaba's "Cross-Border E-Commerce: Alibaba Express" has also highlighted the cross-border logistics issues, and believes that the The knowledge of offshore logistics helps sellers to choose the right logistics method at the right time. On the contrary, if they choose improperly, they may cause both goods and goods, and they also affect the healthy operation of the account. These research results put forward their own opinions on the initial causes of cross-border e-commerce and the framework of development. However, due to the large span of land in China, both the north and the south have great differences in economic and geographical location, especially in the northeast region. With its own geographical and industrial characteristics, the study on cross-border e-commerce in Jilin Province has not yet been seen. This project is based on the theoretical basis of cross-border e-commerce, and analyzes the geographical advantages, industrial structure, and foreign trade development of Jilin Province. Under the guidance of relevant government policies, explore the development path of cross-border ecommerce in Jilin Province.

\section{The Advantages of Cross-Border E-Commerce in Jilin Province}

Jilin Province, with its unique location advantages and climate characteristics, is well-suited to become the hub of intelligent logistics throughout Northeast Asia and even China in the future. As a big data server center, the development strategy of the Jilin New District is also in line with the future development of the Alibaba Group's future agricultural e-commerce, cross-border e-commerce services, and big data. These will give Jilin this traditional agricultural province and old industry. With absolute competitive advantages, through the optimization of the market environment, the construction of an international industrial chain, and the reform of the regulatory system, the crossborder e-commerce industry will usher in a momentum of development.

The current basic situation in Jilin Province lays the foundation for the development of crossborder e-commerce in the future, mainly including the geographical advantage. Jilin Province is an important coastal province near the sea, east of the Japan Sea, bordering Russia's Far East and northern North Korea. According to Ding Haifa, deputy director of the Department of Transportation of Jilin Province, there are currently 11 highway ports in Jilin Province, including one for Russian ports and 10 ports for North Korea; 21 international transport lines have been opened, including 10 against Russia and North Korea. 11; engaged in 40 international road transport companies, and operated more than 1,100 vehicles; initially formed Changchun and Jilin as direct hinterland; Yanbian city as frontier; Hunchun as open window; directly connecting Russia and the DPRK; radiation Northeast Asia's international transportation network. The city of Hunchun, Jilin Province is an important node city on the "Maritime Silk Road" and "Silk Road Economic Belt". It communicates with the Russian and Korean land routes and faces Japan and South Korea across the sea. There are four ports in Hunchun, two for Russia and two for North Korea. In recent years, the implementation of the "One Belt and One Road" initiative of China and the far-reaching development strategy of Russia's Far East have made the exchanges between the two places more frequent. Currently, a quarter of the more than 400 companies set up overseas in Jilin Province are in Russia. The opening 
of the "One Belt and One Road" and cooperation in the Far East has created many business opportunities for Jilin Province.

Followed by collaboration with cross-border e-commerce platforms, Jilin provincial government and Alibaba Group signed a strategic cooperation framework agreement in Changchun. The two parties will jointly create the "Digital Internet Jilin" to boost Jilin Province's comprehensive enhancement of industrial competitiveness, enhance the industrial sustainable development capacity, and promote new breakthroughs in Jilin revitalization. According to the cooperation agreement, both parties will experience shopping in cloud computing and big data, cross-border e-commerce, enterprise e-commerce, rural e-commerce, e-commerce training, smart travel, smart healthcare, smart logistics backbone, and online and offline $(\mathrm{O} 2 \mathrm{O})$ experiential shopping. Centers and other areas carry out in-depth cooperation and explore new ways of cooperation. The agreement also proposes that the two sides will explore the development of cross-border e-commerce development for Russia, Japan, and South Korea, cooperate in the training of electric merchants, cultivate practical and innovative domestic and foreign trade enterprises and rural electric merchants, and jointly promote the construction support of Jilin.

Finally, it is because of the government's policy support. Changchun City, Jilin Province has established Xinglong Bonded Area to vigorously develop cross-border e-commerce, and will soon establish a "Changchun New District", which will drive the transformation and upgrading of foreign trade economy in Jilin Province and Changchun City. The cross-border e-commerce pilot in Changchun City has received the national customs department. A number of home appliance giants are stationed in the Bonded Area; Jilin Province's cross-border trade e-commerce platform is put into trial operation; the cross-border logistics channel construction will be further promoted and will focus on the development of cross-border relations with Russia, South Korea, Japan, North Korea and Mongolia and other countries in Northeast Asia.

\section{Conclusion}

All these aspects have provided advantages for the development of cross-border e-commerce in Jilin Province. Jilin is the source and starting point of the Silk Road in Northeast Asia, and several cities are along the coast. The opening of sea ports will interact with Jilin's overseas markets and interact with domestic coastal cities.

\section{Acknowledgements}

The authors would like to give there thanks to Jilin Social Science Fund (NO.2016B73) \& Changchun Institute of Technology (Research on the Development of Cross-border E-commerce in Jilin Province Under One Belt and One Road Policy)\& College Students Innovation and Entrepreneurship Program of Jilin Province (201611437053) for their financial and technical support.

\section{References}

[1]. Dong Yunhe. Analysis of China's cross-border e-commerce development opportunities under the "One Belt and One Road" strategy background [J]. Contemporary Economy, 2016, (29): 38-40.

[2]. Liu Xiaojun, Zhang Bin. Cooperative development of cross-border e-commerce logistics between China and the "Belt and Road" countries[J]. China's Circulation Economy, 2016, 30(05): 115-120.

[3]. Mu Minghui. Discussion on the promotion of cross-border e-commerce development based on "One Belt and One Road"[J]. Journal of Hubei Correspondence University, 2015,28(23):55-56.

[4]. Zhu Nina, Wu Li. Analysis of potential and trend of cross-border e-commerce development in China under the "One Belt and One Road" strategy [J]. Reform and Strategy, 2015, 31(12): 134137. 